\title{
ANALISIS NILAI TAMBAH HOME INDUSTRY TAHU DAN TEMPE DI KECAMATAN PURWODADI KABUPATEN GROBOGAN
}

\author{
THE ANALYSIS OF ADDED VALUE ON TAHU AND TEMPE HOME INDUSTRY IN \\ PURWODADI SUB DISTRICT GROBOGAN DISTRICT
}

\author{
Yoana Ariadani Manesa \\ Departemen Pertanian \\ Fakultas Peternakan dan Pertanian, Universitas Diponegoro, Semarang. \\ Email : yoanaryanesa@gmail.com \\ Diterima: 14 Nopember 2020, Direvisi: 27 Nopember 2020, Disetujui: 2 Desember 2020
}

\begin{abstract}
ABSTRAK
Penelitian ini bertujuan untuk menganalisis nilai tambah pada industri rumah tangga tahu dan tempe serta menganalisis perbandingan nilai tambah pada industri rumah tangga tahu dan tempe di Kecamatan Purwodadi Kabupaten Grobogan. Metode penelitian yang digunakan yaitu survey dengan jumlah responden sebanyak 11 home industry tempe dan 5 home industry tahu. Metode analisis data yang digunakan yaitu analisis deskriptif untuk mengetahui gambaran umum home industry tahu dan tempe, analisis kuantitatif menggunakan metode Hayami dan uji analisis Mann Whitney menggunakan SPSS. Dari hasil penelitian diketahui bahwa proses pembuatan tempe memerlukan waktu lebih lama yaitu 3-4 hari dalam satu kali produksi dibandingkan proses pembuatan tahu yaitu cukup satu hari dalam satu kali produksi. Nilai tambah home industry tahu dan tempe tergolong tinggi yaitu masing-masing sebesar $\mathrm{Rp} 64.800 / \mathrm{kg}$ kedelai dan $\mathrm{Rp} 37.300 / \mathrm{kg}$ kedelai, namun rasio nilai tambah home industry tahu sebesar $49,09 \%$ relative lebih rendah dari home industry tempe 74,6\%. Hasil analisis Uji Mann Whitney terhadap nilai tambah tahu dan tempe terdapat perbedaan dengan nilai signifikansi 0,000 .
\end{abstract}

Kata kunci: industri rumah tangga, nilai tambah, kedelai, tahu, tempe

\begin{abstract}
This research was purposed to analyze added value on tofu and tempeh home industry and analyze comparison of added value on tofu and tempeh home industry in Purwodadi District, Grobogan Regency. The method used in this research was survey with total of respondents is 11 tempeh home industry and 5 tofu home industry. The data analysis method used is descriptive analysis to find out an overview of the tofu and tempeh home industry and quantitative analysis using the Hayami and the Mann Whitney analysis test using SPSS. From the research, it is known that the process of making tempe takes longer, namely 3-4 days in one production time compared to the process of making tofu wich is only one day in one production. The added value of the tofu and tempeh home industry is classified as high, namely Rp. 64,800/ kg of soybeans and Rp. 37,300/ kg of soybeans, respectively, but the ratio of added value to the tofu home industry is $49.09 \%$, relatively lower than the tempeh home industry of 74.6\%. The results of the Mann Whitney test analysis on the added value of tofu and tempeh that there is a difference with a significance value of 0.000 .
\end{abstract}

Keywords: homeindustry, added value, soybean, tofu, tempe 


\section{PENDAHULUAN}

Indonesia disebut sebagai negara agraris karena sebanyak $31 \%$ penduduk Indonesia mempunyai mata pencaharian di bidang pertanian (Badan Pusat Statistik, 2017). Sebagai negara agraris dengan produksi hasil-hasil pertanian yang beragam, diharapkan dapat menunjang pendapatan nasional melalui pengembangan sektor industri hilir yang ditopang oleh sektor pertanian.

Kedelai merupakan salah satu komoditas tanaman pangan strategis di Indonesia. Total produksi kedelai di Indonesia sebesar 982.598 ton, sedangkan kebutuhan kedelai nasional mencapai 3,36 juta ton (Badan Pusat Statistik, 2016). Hal tersebut mengharuskan pemerintah melakukan kegiatan impor kedelai. Kedelai yang pemenuhan kebutuhannya secara nasional didominasi impor, seharusnya digunakan bagi kegiatan yang mampu memberikan nilai tambah yang tinggi. Kedelai tidak hanya digunakan bagi kegiatan konsumsi secara langsung, tetapi juga mengarah pada aktifitas yang dapat meningkatkan nilai tambah bagi komoditas tersebut. Sebagai salah satu contohnya adanya industri pengolahan kedelai menjadi produk tahu dan tempe.

Tahu sering kali disebut daging tidak bertulang karena kandungan gizinya, terutama mutu protein setara dengan daging hewan. Bahkan, protein tahu lebih tinggi dibandingkan protein kedelai (Saragih, 2001). Tempe adalah pangan asli Indonesia yang dibuat dari bahan baku kedelai melalui proses fermentasi oleh Rhizopus sp. Selain sebagai zat gizi, tempe juga memiliki manfaat untuk menjaga kesehatan tubuh. Tempe mengandung senyawa anti bakteri yang aktif melawan bakteri gram positif dan bakteri penyebab diare (Haliza et al., 2016). Oleh karena itu upaya meningkatkan asupan protein untuk tubuh, dapat dilakukan dengan melakukan peningkatan konsumsi pada produk olahan kacang kedelai berupa tahu dan tempe. Berdasarkan hal tersebut serta seiring dengan peningkatan jumlah penduduk Indonesia, kebutuhan konsumsi protein harian masyarakat Indonesia yang berasal dari kedelai pun ikut meningkat.

Kabupaten Grobogan merupakan salah satu daerah penyumbang produksi kedelai terbesar di Jawa Tengah. Total produksi kedelai tahun 2018 di Kabupaten Grobogan mencapai 54.065 ton, sedangkan total produksi kedelai Provinsi Jawa Tengah sebesar 129.794 ton. Hal tersebut menunjukkan bahwa sebanyak $37 \%$ produksi kedelai di Jawa Tengah dihasilkan dari Kabupaten Grobogan (Badan Pusat Statistik Jawa Tengah, 2018). Melihat adanya potensi produksi kedelai yang cukup baik di Kabupaten Grobogan, maka perlu diupayakan untuk memberikan ruang terhadap berkembangnya industri dengan memanfaatkan potensi produksi kedelai yang ada.

Potensi industri tahu dan tempe di Kecamatan Purwodadi, Kabupaten Grobogan cukup besar karena jumlah produksi kedelai di Kecamatan tersebut cukup tinggi yaitu sebesar 3.089 ton pada tahun 2018 (Badan Pusat Statistik Grobogan, 2019).

Mengingat pula sebagian besar produksi kedelai diolah menjadi bahan pangan yang siap dikonsumsi baik secara langsung maupun tidak langsung seperti tahu dan tempe. Adanya industri juga merupakan penggerak utama dalam perkembangan sektor pertanian (Budiman et al., 2014). Selama ini nilai tambah hasil pertanian belum dimanfaatkan dengan baik, padahal dengan perkembangan teknologi sangat memungkinkan terbukanya peluang baru untuk manghasilkan produk-produk pertanian yang berkualitas. Hasil pertanian yang mudah rusak juga dapat dijadikan alasan untuk mengembangkan hasil pertanian dengan menciptakan nilai tambah menjadi suatu produk 
(Pratama, 2015). Analisis nilai tambah dari produk olahan kedelai penting dilakukan untuk dapat mengetahui tinggi rendahnya nilai tambah yang dihasilkan suatu usaha tersebut. Selain itu dengan dilakukannya analisis nilai tambah ini dapat untuk mengukur balas jasa yang diterima pelaku sistem (pengolah) dan kesempatan kerja yang dapat diciptakan oleh sistem tersebut. Dari besaran nilai tambah yang dihasilkan dapat ditaksir besarnya balas jasa yang diterima faktor produksi yang digunakan dalam proses pengolahan tersebut.

Penelitian ini bertujuan untuk menganalisis nilai tambah home industry tahu dan tempe di Kecamatan Purwodadi Kabupaten Grobogan serta menganalisis perbandingan nilai tambah home industry tahu dan tempe di Kecamatan Purwodadi Kabupaten Grobogan.

\section{METODE PENELITIAN}

Penelitian dilakukan pada Januari April 2018 di Kecamatan Purwodadi.
Metode yang digunakan dalam penelitian ini adalah survei dengan menggunakan kuesioner sebagai instrumen pengumpulan data. Metode pengambilan sampel dilakukan dengan metode sensus, dimana semua populasi digunakan sebagai sampel. Responden penelitian ini terdiri dari 5 home industry tahu dan 11 home industry tempe.

Metode analisis data yang digunakan adalah analisis deskriptif dan analisis kuantitatif. Analisis deskriptif digunakan untuk mengetahui gambaran umum home industry tahu dan tempe. Analisis kuantitaif digunakan untuk mengetahui besarnya nilai tambah yang dihasilkan pada home industry tahu dan tempe serta untuk mengetahui perbandingan antara nilai tambah home industry tahu dan tempe, yaitu analisis perhitungan Nilai Tambah Metode Hayami dan analisis Independent sample $t$ test yang dapat dilihat pada Tabel 1 berikut:

Tabel 1. Nilai Tambah Metode Hayami

\begin{tabular}{|c|c|c|}
\hline No & Variabel (Output, Input, Harga) & Notasi \\
\hline 1. & Hasil Produksi Output (kg/bulan) & $\mathrm{A}$ \\
\hline 2. & Input Bahan Baku (kg/bulan) & $\mathrm{b}$ \\
\hline 3. & Input Tenaga Kerja (HOK/bulan) & $\mathrm{c}$ \\
\hline 4. & Faktor Konversi $(1 / 2)$ & $\mathrm{d}=\mathrm{a} / \mathrm{b}$ \\
\hline 5. & Koefisien Tenaga Kerja (3/2) & $\mathrm{e}=\mathrm{c} / \mathrm{b}$ \\
\hline 6. & Harga Produk Output (Rp/kg) & $\mathrm{f}$ \\
\hline 7. & Upah Tenaga Kerja (Rp/HOK) & $\mathrm{g}$ \\
\hline \multicolumn{3}{|c|}{ Pendapatan dan Keuntungan } \\
\hline 8. & Harga Input Bahan Baku (Rp/kg) & $\mathrm{h}$ \\
\hline & Sumbangan Imput Lain $(\mathrm{Rp} / \mathrm{kg})$ & I \\
\hline & Nilai Produk $(\mathrm{Rp} / \mathrm{kg})(4 \times 6)$ & $j=d \times f$ \\
\hline & a. Nilai Tambah $(\mathrm{Rp} / \mathrm{kg})(10-8-9)$ & $\mathrm{k}=\mathrm{j}-\mathrm{h}-\mathrm{i}$ \\
\hline & b. Ratio Nilai Tambah (\%) (11a/10) & $\mathrm{l}=\mathrm{k} / \mathrm{j} \times 100 \%$ \\
\hline & a. Pendapatan Tenaga Kerja (Rp/HOK) $(5 \times 7)$ & $\mathrm{m}=\mathrm{e} \times \mathrm{g}$ \\
\hline & b. Pangsa Tenaga Kerja (\%) (12a/11a) & $\mathrm{n}=\mathrm{m} / \mathrm{k} \times 100 \%$ \\
\hline & a. Keuntungan (Rp) $(11 \mathrm{a}-12 \mathrm{a})$ & $\mathrm{o}=\mathrm{k}-\mathrm{m}$ \\
\hline & b. Tingkat Keuntungan (\%) (13a/11a) & $\mathrm{p}=\mathrm{o} / \mathrm{j} \times 100 \%$ \\
\hline
\end{tabular}

Sumber : Hayami et al., 1987. 
Ada tiga indikator rasio nilai tambah (Reyne dalam Azmita et al, 2019) yaitu:

1. Jika besarnya rasio nilai tambah $<15 \%$, maka nilai tambah tergolong rendah

2. Jika besarnya rasio nilai tambah 15$40 \%$, maka nilai tambah tergolong sedang

3. Jika besarnya rasio nilai tambah $>40 \%$, maka nilai tambah tergolong tinggi.

\section{Uji Normalitas}

Pengujian normalitas dilakukan untuk mengetahui normal atau tidaknya distribusi suatu data. Uji analisis normalitas menggunakan uji Kolmogorov Smirnov. Kriteria data berdistribusi normal apabila nilai Sig $>0,05$. Data berdistribusi tidak normal apabila nilai Sig $<$ 0,05 (Santoso, 2010). Data yang memiliki distribusi normal dapat menggunakan uji parametrik, namun apabila data memiliki distribusi yang tidak normal maka dapat menggunakan uji non parametric sebagai alternatif (Siagian dan Sugiarto, 2006).

\section{Uji Mann-Whitney}

Uji Mann-Whitney merupakan uji non-parametrik sebagai alternative dari uji Independent sample t test yang digunakan untuk mengetahui ada tidaknya perbedaan antara dua sampel yang independen (Harinaldi, 2005).

Hipotesis

Ho $: \mu \mathrm{a}=\mu \mathrm{b}$, diduga tidak terdapat perbedaan nilai tambah pembuatan tahu dengan nilai tambah pembuatan tempe.

Ha $: \mu \mathrm{a} \neq \mu \mathrm{b}, \quad$ diduga terdapat perbedaan nilai tambah pembuatan tahu dengan nilai tambah pembuatan tempe.

Keterangan :

$\mu \mathrm{a}=$ nilai tambah pembuatan tahu $(\mathrm{Rp} / \mathrm{kg})$ $\mu \mathrm{b}=$ nilai tambah pembuatan tempe $(\mathrm{Rp} / \mathrm{kg})$

Kriteria penilaian pada aplikasi SPSS dilihat dari nilai Sig. (2 tailed), apabila nilainya lebih kecil dari 0,05 maka Ho ditolak dan Ha diterima, sedangkan apabila nilainya lebih besar dari 0,05 maka Ho diterima dan Ha ditolak (Santoso, 2010).

\section{HASIL DAN PEMBAHASAN Keadaan Umum}

Kabupaten Grobogan terletak diantara $110^{\circ} 32^{\prime}-110^{\circ} 15^{\prime}$ bujur timur dan $6^{\circ} 55^{\prime}-7^{\circ} 16^{\prime}$ lintang selatan. Kabupaten Grobogan mempunyai luas lahan 197.586 hektar yang terdiri dari 66.184 (33,5\%) hektar lahan pertahian sawah, 99.674 $(50,4 \%)$ lahan pertanian bukan sawah dan $31.728(16,1 \%)$ hektar lahan bukan pertanian. Kabupaten Grobogan merupakan salah satu daerah penyumbang produksi kedelai terbesar di Jawa Tengah. Total produksi kedelai tahun 2018 di Kabupaten Grobogan mencapai 54.065 ton. Hampir semua kecamatan di Kabupaten Grobogan terdapat lahan penghasil kedelai.

Kedelai merupakan salah satu komoditas andalan dalam pertanian di Kabupaten Grobogan. Secara topografi yang sesuai dengan karakteristik tanah Kabupaten Grobogan, membuat komoditas ini banyak diusahakan oleh petani yang ada di wilayah tersebut. Oleh karena itu, komoditas kedelai juga dapat tumbuh dengan subur serta dapat menguntungkan saat dibudidayakan oleh petani. Bahkan, telah dipatenkan benih unggul dengan nama kedelai varietas Grobogan yang telah dikembangkan di wilayah tersebut. Kedelai varietas ini lebih banyak diminati petani karena secara teknis lebih tahan akan penyakit, kualitas biji yang dihasilkan dinilai bagus dan waktu panennya cepat. 


\section{Profil Responden}

Jumlah responden yang dijadikan sampel yaitu 5 home industry tahu dan 11 home industry tempe yang dapat dilihat pada Tabel 2 berikut :

Tabel 2.

Profil Responden

\begin{tabular}{|c|c|c|c|c|c|}
\hline \multirow{2}{*}{ No. } & \multirow{2}{*}{ Profil Responden } & \multicolumn{2}{|c|}{ Home industry Tempe } & \multicolumn{2}{|c|}{ Home industry Tahu } \\
\hline & & Jumlah & Persentase & Jumlah & Persentase \\
\hline & & ---orang--- & ----\%---- & ---orang--- & ----\%---- \\
\hline \multirow[t]{6}{*}{1.} & Usia (Tahun) & & & & \\
\hline & $21-30$ & - & - & - & - \\
\hline & $31-40$ & 3 & 27,28 & - & - \\
\hline & $41-50$ & 3 & 27,28 & 3 & 60 \\
\hline & $51-60$ & 5 & 45,44 & 1 & 20 \\
\hline & $61-70$ & - & - & 1 & 20 \\
\hline \multirow[t]{5}{*}{2.} & Tingkat Pendidikan & & & & \\
\hline & $\mathrm{SD}$ & - & - & - & - \\
\hline & SMP & 4 & 36,36 & - & - \\
\hline & SMA & 7 & 63,64 & 5 & 100 \\
\hline & Perguruan Tinggi & - & - & - & - \\
\hline \multirow[t]{6}{*}{3.} & Lama Berusaha (tahun) & & & & \\
\hline & $1-10$ & 2 & 18,18 & 1 & 20 \\
\hline & $11-20$ & 3 & 27,27 & 3 & 60 \\
\hline & $21-30$ & 5 & 45,45 & - & - \\
\hline & $31-40$ & 1 & 9,1 & 1 & 20 \\
\hline & $>41$ & - & - & - & - \\
\hline
\end{tabular}

Sumber: Data Primer 2018

Berdasarkan Tabel 2 diketahui bahwa usia pengrajin home industry tempe sebanyak $27,28 \%$ pada rentang usia $31-40$ tahun, sebanyak $27,28 \%$ pada rentang usia 41-50 dan sebanyak 45,44\% pada rentang usia 51-60. Sedangkan pada pengrajin home industry tahu sebanyak $60 \%$ pada rentang usia 41-50, 20\% pada rentang usia 51-60 dan 20\% sisanya pada rentang usia 61-70. Dari data tersebut terlihat bahwa pengrajin tahu dan tempe termasuk dalam usia yang produktif. Hal ini sesuai dengan pendapat (Soehyonoet al, 2014) yang menyatakan bahwa usia produktif adalah penduduk yang berumur 15 sampai usia 64 tahun.

Tingkat pendidikan pengrajin tempe sebanyak $63,64 \%$ berpendidikan terakir SMA sama halnya dengan pengrajin tahu sebanyak $100 \%$ berpendidikan terakir SMA. Hal ini menunjukkan para pengrajin tempe dan tahu sudah berpendidikan cukup untuk dapat membekali diri dalam mengembangkan usahanya. Hal ini didukung dengan pendapat (Sutrisno, 2006) yang menyatakan bahwa tingkat pendidikan yang telah dicapai oleh seseorang dapat mempengaruhi tingkat pengetahuan, pola pikir, sikap dan cara pemgambilan keputusan.

Lama usaha pengrajin tempe paling besar pada rentang 21-30 tahun sebesar $45,45 \%$ dan untuk pengrajin tahu paling besar pada rentang 11-20 tahun sebesar $60 \%$. Tingkat keberhasilan suatu 
usaha tidak hanya dilihat dari seberapa tinggi pendidikan yang telah ditempuh tetapi juga seberapa lama pengalaman yang sudah dijalani selama berusaha. Karena dengan rentang waktu yang sudah cukup lama dalam berusaha, akan lebih banyak pengalaman, ilmu serta keahlian yang akan didapat selama menjalankan usahanya. Hal ini sesuai dengan pendapat (Soehyono et al, 2017), yang menyatakan bahwa keberhasilan usaha agroindustri tidak hanya ditentukan oleh tingkat pendidikan, tetapi juga ditentukan oleh pengalaman berusahanya.

\section{Proses Pengolahan Tahu}

Home industry tahu di Kecamatan Purwodadi sebagian besar merupakan usaha turun temurun. Proses pengolahan tahu dilakukan setiap hari oleh pelaku usaha yang dimulai dari pukul 08.0016.00. Tahu yang di produksi yaitu jenis tahu putih, dimana dalam proses pengolahan tahu ini para pelaku usaha dibantu oleh beberapa karyawan yang berasal dari dalam keluarga maupun luar keluarga. Penggunaan tenaga kerja ratarata 2-4 orang dalam pengolahan tahu. Proses pengolahan dari kedelai sampai menjadi tahu memerlukan waktu satu hari, lebih cepat jika dibandingkan proses pengolahan kedelai menjadi tempe yang membutuhkan waktu 3-4 hari. Rata-rata tahu yang diproduksi sudah menjadi langganan para pedagang tahu yang ada di pasar. Tetapi, tak sedikit pula yang menjual sendiri kepada pedagangpedagang tahu yang ada di pasar maupun langsung kepada konsumen.

Tahap pembuatan tahu dimulai dengan pencucian kedelai dengan air bersih, kemudian dilakukan perendaman kurang lebih selama 5-6 jam pada emberember kecil dimana per ember bisa memuat kurang lebih $8 \mathrm{~kg}$ kedelai. Setelah itu, kedelai dicuci kembali dengan air bersih. Kemudian dilakukan proses penghancuran kedelai menggunakan alat penggiling sampai menjadi seperti bubur kedelai. Setelah proses penggilingan, dilakukan proses perebusan bubur kedelai hingga mendidih seperti muncul gelembung-gelembung kecil kurang lebih 20-30 menit. Setelah bubur kedelai sedikit mengental kemudian diangkat dan disaring menggunakan kain penyaring sambil menambahkan asam cuka yang dianduk perlahan hingga bubur kedelai menggumpal. Penambahan cuka tidak dilakukan setiap kali proses pengolahan, sesekali menggunakan air sisa proses pengolahan tahu sebelumnya yang telah didiamkan 1-2 hari. Bubur kedelai yang sudah disaring kemudian dipress untuk menekan ampas agar kandungan airnya habis. Setelah itu tahu siap dicetak di papan cetakan tahu. Pencetakan tahu pada setiap usaha berbeda-beda, tetapi rata-rata setiap papan dapat menghasilkan 100 potong tahu.

\section{Proses Pengolahan Tempe}

Home industry tempe yang ada di Kecamatan Purwodadi sebagian besar mendirikan usahanya untuk menambah penghasilan. Proses pengolahan tempe juga dilakukan setiap hari. Pengolahan tempe membutuhkan waktu lebih lama karena adanya proses fermentasi kedelai. Membutuhkan waktu 3-4 hari sampai kedelai menjadi tempe. Walaupun prosesnya memakan waktu yang cukup lama, tetapi para pengrajin tempe tetap melakukan produksi setiap hari sambil menunggu proses fermentasi pada produksi sebelumnya. Proses pengolahan tempe dimulai dari pukul 08.00-14.00. Tempe yang diproduksi adalah tempe berbungkus plastik, dimana tempe ini dijual langsung ke pasar maupun ke pedagang untuk dijual kembali. Penggunaan tenaga kerja rata-rata 2-3 orang yang berasal dari keluarga maupun luar keluarga. Hal ini sesuai dengan (Badan Pusat Statistik, 2014) yang menyatakan 
bahwa industri rumah tangga merupakan perusahaan atau industri pengolahan yang menggunakan atau mempunyai tenaga kerja sebanyak 1-4 orang.

Proses produksi dari kedelai sebelum menjadi tempe dimulai dengan pencucian kedelai dengan air bersih. Kemudian kedelai direbus kurang lebih 30 menit atau sampai setengah matang. Setelah kedelai direbus kemudian ditiriskan dan direndam dalam air kurang lebih 1 malam. Hal ini bertujuan untuk membuat kondisi asam pada kedelai. Setelah direndam 1 malam, kedelai kemudian dipisahkan dari kulitnya atau pemecahan kedelai dengan cara menggunakan alat ataupun secara manual yaitu diinjak-injak yang kemudian dicuci lagi menggunakan air bersih.
Tahap selanjutnya kedelai direbus kembali sampai matang yang kemudian setelah matang ditiriskan dan dianginanginkan. Pengeringan kedelai ini dilakukan dengan meletakkan kedelai di atas terpal ataupun meja seperti dijemur agar kedelai terkena angin. Kemudian dilakukan pemberian ragi yang dicampur pada kedelai. Kedelai siap dikemas dalam wadah plastik yang kemudian disusun pada rak kayu untuk menunggu proses fermentasi kurang labih selama 2 hari.

\section{Penggunaan Faktor Produksi Tahu}

Penggunaan faktor produksi dalam proses pembuatan tahu dapat dilihat pada Tabel 3 berikut :

Tabel 3.

Penggunaan Faktor Produksi Tahu

\begin{tabular}{lllr}
\hline \hline No & \multicolumn{1}{c}{ Faktor Produksi } & \multicolumn{1}{c}{ Penggunaan } & \multicolumn{1}{c}{ Nilai } \\
\hline & & & -- Rp-- \\
1. & Kedelai & $1.266 \mathrm{~kg}$ & 9.115 .200 \\
2. & Cuka & 8 liter & 480.000 \\
3. & Air & 1 bulan & 410.000 \\
4. & Berambut sekam & $132 \mathrm{sak}$ & 726.000 \\
\hline
\end{tabular}

Sumber : Data Primer 2018

Berdasarkan Tabel 3 diketahui bahwa penggunaan faktor-faktor produksi dalam menunjang proses produksi tahu antara lain kedelai, cuka, air dan brambut sekam. Rata-rata penggunaan kedelai dalam 1 bulan proses produksi tahu membutuhkan kedelai sebanyak $1.266 \mathrm{~kg}$. Dimana kedelai ini dibeli dengan harga rata-rata $\mathrm{Rp} \mathrm{7.200/kg} \mathrm{sehingga} \mathrm{pengrajin}$ tahu mengeluarkan biaya sebanyak Rp 9.115.200,- untuk kebutuhan bahan baku tahu. Rata-rata pengrajin tahu maupun tempe memperoleh kedelai dari agen yang sudah berlangganan maupun koperasi setempat. Kedelai yang digunakan sebagian besar menggunakan kedelai impor, walaupun tidak jarang juga menggunakan kedelai lokal. Pengrajin tahu lebih menyukai pemakaian kedelai impor karena dinilai kualitasnya lebih bagus yang dilihat dari ukurannya yang besar, seragam dan hasilnya lebih bagus. Berbeda dengan pendapat para ahli, menurut pemaparan Direktur Aneka Kacang-kacangan dan Umbu-umbian Kementerian Pertanian (dalam Chrismahendra, 2017) yang menyatakan bahwa kedelai lokal lebih unggul dari pada kedelai impor dalam hal bahan baku pembuatan tahu. Rasa yang dihasilkan oleh kedelai lokal lebih lezat, rendemennya pun lebih tinggi dan resiko 
terhadap kesehatan cukup rendah karena bukan benih transgenik.

Penggunaan cuka pada proses pembuatan tahu bertujuan untuk mengandapkan serta menggumpalkan protein tahu sehingga terjadi pemisahan whey dengan gumpalan tahu. Pemberian cuka tidak boleh terlalu banyak karena akan menimbulkan rasa asam pada tahu. Rata-rata penggunakan asam cuka pada pengrajin tahu sebanyak 8 liter untuk 1 bulan proses produksi. Sehingga pengrajin tahu memerlukan biaya sebesar Rp 480.000,- untuk pembelian cuka. Untuk penggunaan air rata-rata dalam 1 bulan sebanyak Rp 410.000,-. Dimana air ini digunakan untuk proses perendaman kedelai, pencucian kedelai maupun untuk proses pemasakan kedelai.
Penggunaan berambut sekam digunakan dalam proses perebusan bubur kedelai. Rata-rata dibutuhkan sebanyak 132 sak dalam 1 bulan proses produksi. Harga berambut sekam ini Rp 5.500/sak, sehingga pengrajin tahu membutuhkan biaya sebanyak Rp 726.000,- untuk bahan bakar perebusan bubur kedelai. Penggunaan berambut sekam ini dinilai lebih murah dibandingkan penggunaan kayu bakar apalagi gas elpiji. Volume penggunaan dalam proses pemasakan bubur kedelai juga dinilai lebih sedikit dibandingkan dengan menggunakan kayu bakar.

\section{Penggunaan Faktor Produksi Tempe}

Penggunaan faktor produksi dalam proses pembuatan tahu dapat dilihat pada Tabel 4 berikut :

Tabel 4.

Penggunaan Faktor Produksi Tempe

\begin{tabular}{lllr}
\hline \hline No & \multicolumn{1}{c}{ Faktor Produksi } & \multicolumn{1}{c}{ Penggunaan } & \multicolumn{1}{c}{ Nilai } \\
\hline & & & $---R p---$ \\
1. & Kedelai & $1.200 \mathrm{~kg}$ & 8.640 .200 \\
2. & Ragi & 3 bungkus & 16.500 \\
3. & Kayu bakar & 30 ikat & 180.000 \\
4. & Plastik & 60 pack & 420.000 \\
\hline
\end{tabular}

Sumber : Data Primer 2018

\begin{abstract}
Berdasarkan Tabel 4 diketahui bahwa penggunaan faktor produksi pembuatan tempe terdiri dari kedelai, ragi, air, kayu bakar dan plastik. Penggunaan kedelai untuk proses produksi rata-rata dalam 1 bulan produksi pengrajin tempe menggunakan kedelai sebanyak $1.200 \mathrm{~kg}$. Kedelai ini didapat dengan harga rata-rata Rp 7.200/kg. Sehingga rata-rata biaya yang dibutuhkan untuk bahan baku pembuatan tempe sebesar Rp 8.640.200,-.

Kedelai yang digunakan umumnya berwarna kuning dan bulat. Hal ini sesuai dengan pendapat (Wardani, 2008) yang menyatakan bahwa industri tempe pada
\end{abstract}

umumnya menggunakan kedelai kuning (Glicyne max) sebagai bahan baku karena menghasilkan warna dan tekstur yang disukai konsumen, serta cita rasa yang nikmat. Sama halnya dengan pengrajin tahu, sebagian besar kedelai yang digunakan pada pengolahan tempe adalah kedelai impor, walaupun tidak jarang juga memakai kedelai lokal. Pengrajin tempe lebih menyukai kedelai impor karena dirasa kualitasnya lebih bagus, ukurannya yang lebih besar dan seragam. Penggunaan kedelai impor juga dinilai lebih cepat dalam proses fermentasi dibandingkan kedelai lokal. Hal ini sependapat oleh 
penelitian (Anggraini, 2017) yang berpendapat bahwa industri tempe sangat tergantung dan lebih menyukai menggunakan kedelai impor karena kualitas kedelai impor lebih seragam, butiranbutiran lebih besar, harga relatif lebih murah daripada kedelai lokal. Industri tempe lebih menyukai menggunakan kedelai impor karena tempe yang dihasilkan memiliki penampilan dan rasa yang lebih unggul, tidak menghasilkan bau langu atau bau khas yang terdapat pada tempe yang menggunakan kedelai lokal.

Ragi merupakan komponen penting dalam proses pembuatan tempe, karena ragi merupakan komponen yang membantu berlangsungnya proses fermentasi. Dosis pemberian ragi yang kurang tepat juga akan mempengaruhi proses fermentasi kedelai untuk menjadi tempe. Penggunaan ragi untuk $1 \mathrm{~kg}$ kedelai kirakira cukup dengan 1 gram pemberian. Sehingga untuk pemberian ragi pada 1.200 $\mathrm{kg}$ kedelai selama 1 bulan proses produksi dibutuhkan ragi kurang lebih 3 bungkus ragi kemasan 500 gram. Dimana ragi ini dibeli dengan harga Rp 5.500/kemasan isi 500 gram. Sehingga total pengeluaran pengrajin tempe untuk membeli ragi sebesar Rp 16.500,-. Pemberian ragi pada cuaca yang panas tidak perlu terlalu banyak. Tetapi untuk cuaca dingin dianjurkan tetap sesuai dengan dosis yang tertera pada kemasan. Hal ini didukung oleh pendapat (Anggraini, 2017) yang menyatakan bahwa pengrajin tempe menggunakan ragi rata-rata sebanyak 1,08 gram untuk $1 \mathrm{~kg}$ kedelai yang difermentasi. Anjuran dosis yang tertulis di kemasan ragi adalah 2 gram ragi untuk $1 \mathrm{~kg}$ kedelai. Pengrajin tempe menurunkan dosis karena berdasarkan pengalaman, pemberian ragi setengah dosis pada kondisi cuaca panas diperkirakan cukup untuk memfermentasi kedelai menjadi tempe.

Kayu bakar yang dibutuhkan pengrajin tempe dalam 1 bulan proses produksi rata-rata 30 ikat kayu dengan harga Rp 6.000/ikat. Dimana dalam 1 kali perebusan kedelai kira-kira dibutuhkan kayu setengah ikat tanpa memperhatikan jumlah kedelai yang direbus. Pemilihan kayu bakar dikarenakan biaya yang lebih murah dibandingkan penggunaan gas.

Pembungkusan tempe dapat menggunakan daun pisang maupun plastik. Dimana plastik yang digunakan untuk membungkus tempe rata-rata sebanyak 60 pack dengan harga Rp 7.000,-/pack sehingga pengrajin tempe membutuhkan biaya sebanyak Rp 420.000,- untuk keperluan pembelian plastik. Sebenarnya penggunaan pembung-kus daun pisang lebih bagus dibandingkan plastik karena dengan menggunakan daun pisang akan akan memberikan kesan kedelai tersimpan pada ruang yang gelap dimana ini merupakan salah satu syarat terjadinya fermentasi. Tetapi para pengrajin tempe lebih memilih menggunakan plastik karena dinilai lebih praktis. Hal ini sesuai dengan pendapat (Hidayat et al, 2006) yang menyatakan bahwa pengrajin tempe pada umumnya menggunakan dua jenis pembungkus yaitu daun pisang dan plastik. Kantong plastik juga dapat digunakan untuk membungkus tempe, namun karena bersifat kedap udara maka permukaan plastik harus dilubangi supaya aerasi dapat terjadi. Faktor utama yang menentukan bahwa pembungkus dapat menghasilkan tempe yang baik ialah aerasi dan kelembaban.

\section{Analisisi Nilai Tambah Tahu}

Analisis nilai tambah pada proses produksi tahu dapat dilihat pada Tabel 5 berikut : 
Tabel 5.

Analisis Nilai Tambah Tahu

\begin{tabular}{clr}
\hline \hline No & \multicolumn{1}{c}{ Variabel (Output, Input, Harga) } & Nilai \\
\hline 1. & Hasil Produksi Output (buah/bulan) & 27.852 \\
2. & Input Bahan Baku (kg/bulan) & 1.266 \\
3. & Input Tenaga Kerja (HOK/bulan) & 123 \\
4. & Faktor Konversi (1/2) & 22 \\
5. & Koefisien Tenaga Kerja (3/2) & 0,10 \\
6. & Harga Produk Output (Rp/kg) & 6.000 \\
7. & Upah Tenaga Kerja (Rp/HOK) & 32.000 \\
\hline & $\quad$ Pendapatan dan Keuntungan \\
\hline 8. & Harga Input Bahan Baku (Rp/kg) & 7.200 \\
9. & Sumbangan Imput Lain (Rp/kg) & 60.000 \\
10. & Nilai Produk (Rp/kg) (4x6) & 132.000 \\
11. & a. Nilai Tambah (Rp/kg) (10-8-9) & 64.800 \\
& b. Ratio Nilai Tambah (\%) (11a/10) & 49,09 \\
12. & a. Pendapatan Tenaga Kerja (Rp/HOK) (5x7) & $3.109,00$ \\
& b. Pangsa Tenaga Kerja (\%) (12a/11a) & 4,80 \\
13. & a. Keuntungan (Rp) (11a-12a) & $61.691,00$ \\
& b. Tingkat Keuntungan (\%) (13a/11a) & 46,74 \\
\hline
\end{tabular}

Sumber : Data Primer 2018

Berdasarkan Tabel 5 dapat diketahui bahwa dalam satu bulan produksi tahu rata-rata membutuhkan kedelai sebanyak $1.266 \mathrm{~kg}$ dengan harga per kg kedelai sebesar Rp 7.200,-. Menghasilkan 27.852 buah tahu dengan harga jual Rp 10.000,-/kg. Upah tenaga kerja Rp 32.000,- dengan jumlah jam kerja rata-rata sekali proses produksi selama 8 jam. Harian Orang Kerja (HOK) sebesar 123/bulan.

Perbandingan jumlah output dan input akan menghasilkan nilai faktor konversi sebesar 22 yang artinya setiap satu kg kedelai menghasilkan 22 buah tahu Input tenaga kerja dibagi dengan input bahan baku akan menghasilkan koefisiensi tenaga kerja sebesar 0,10 yang artinya setiap mengolah satu $\mathrm{kg}$ kedelai membutuhkan 0,10 HOK.

Nilai tambah yang diperoleh sebesar Rp 64.800,- dengan tingkat persentase sebesar $49,09 \%$. Nilai tambah ini diperoleh dari hasil pengurangan nilai produk dikurangi harga input bahan baku dikurangi sumbangan input lain. Nilai tambah tersebut tergolong tinggi karena lebih dari $40 \%$. Hal ini sesuai dengan pendapat (Reyne dalam Azmita et al, 2019) yang menyatakan bahwa ada tiga indikator rasio nilai tambah yaitu 1). Rasio nilai tambah $<15 \%$, maka nilai tambah tergolong rendah, 2). Rasio nilai tambah 15-40\%, maka nilai tambah tergolong sedang, 3). Rasio nilai tambah $>40 \%$, maka nilai tambah tergolong tinggi. Pendapatan tenaga kerja diperoleh dari koefisien tenaga kerja dikalikan upah tenaga kerja dan diperoleh hasil sebesar Rp 3.109,- dengan persentase sebesar $4,8 \%$. Keuntungan yang diperoleh sebesar Rp 61.691,- per kg tahu dengan tingkat persentase sebesar $46,74 \%$.

Hal ini didukung oleh pendapat (Wiyono dan Rukavina, 2015) yang menyatakan bahwa analisis nilai tambah merupakan metode perkiraan sejauh mana bahan baku yang mendapat perlakuan 
mengalami perubahan nilai, sehingga dapat memberikan nilai tambah yang dipengaruhi proses produksi.

\section{Analisis Nilai Tambah Tempe}

Analisis nilai tambah pada proses produksi tempe dapat dilihat pada Tabel 6 berikut:

Tabel 6.

Analisis Nilai Tambah Tempe

\begin{tabular}{clr}
\hline \hline No & \multicolumn{1}{c}{ Variabel (Output, Input, Harga) } & Nilai \\
\hline 1. & Hasil Produksi Output (buah/bulan) & 6.000 \\
2. & Input Bahan Baku (kg/bulan) & 1.200 \\
3. & Input Tenaga Kerja (HOK/bulan) & 71 \\
4. & Faktor Konversi (1/2) & 5 \\
5. & Koefisien Tenaga Kerja (3/2) & 0,06 \\
6. & Harga Produk Output (Rp/kg) & 10.000 \\
7. & Upah Tenaga Kerja (Rp/HOK) & 52.000 \\
\hline & $\quad$ Pendapatan dan Keuntungan \\
\hline 8. & Harga Input Bahan Baku (Rp/kg) & 7.200 \\
9. & Sumbangan Imput Lain (Rp/kg) & 5.500 \\
10. & Nilai Produk (Rp/kg) (4x6) & 50.000 \\
11. & a. Nilai Tambah (Rp/kg) (10-8-9) & 37.300 \\
& b. Ratio Nilai Tambah (\%) (11a/10) & 74,6 \\
12. & a. Pendapatan Tenaga Kerja (Rp/HOK) (5x7) & $3.076,67$ \\
& b. Pangsa Tenaga Kerja (\%) (12a/11a) & 8,25 \\
13. & a. Keuntungan (Rp) (11a-12a) & $34.223,33$ \\
& b. Tingkat Keuntungan (\%) (13a/11a) & 68,45 \\
\hline
\end{tabular}

Sumber : Data Primer 2018

Berdasarkan data pada Tabel 6, dapat diketahui bahwa penggunaan bahan baku dalam satu bulan produksi rata-rata sebanyak $1.200 \mathrm{~kg}$ kedelai dengan harga per $1 \mathrm{~kg}$ kedelai sebesar Rp 7.200,- dan dapat menghasilkan output berupa tempe sebanyak 6.000 buah dengan harga jual Rp $10.000,-$ per $\mathrm{kg}$ tempe. Upah rata-rata tenaga kerja $\mathrm{Rp} 52.000$,-/hari dengan jumlah jam kerja rata-rata sekali proses produksi sebanyak 6 jam. Harian Orang Kerja (HOK) sebesar 71/bulan. Perbandingan jumlah output dan input akan menghasilkan nilai faktor konversi sebesar 5 yang artinya dalam pengolahan satu kg kedelai akan menghasilkan 5 buah tempe. Input tenaga kerja dibagi dengan input bahan baku akan menghasilkan koefisiensi tenaga kerja sebesar 0,06 yang artinya untuk mengolah satu $\mathrm{kg}$ kedelai membutuhkan 0,06 HOK.

Nilai tambah yang diperoleh dari hasil pengolahan satu $\mathrm{kg}$ kedelai menjadi tempe sebesar Rp. 37.300,- yang diperoleh dari hasil pengurangan nilai produk dikurangi harga input bahan baku dikurangi sumbangan input lain. Rasio nilai tambah yang diperoleh sebesar $74,6 \%$, yang artinya setiap pengolahan kacang kedelai menjadi tempe memberikan nilai tambah sebesar 74,6\% dari nilai produk. Nilai tambah tersebut tergolong tinggi karena lebih dari $40 \%$. Hal ini sesuai dengan pendapat (Reyne dalam Azmita et al, 2019) yang menyatakan bahwa ada tiga indikator rasio nilai tambah yaitu 1). Rasio nilai tambah < $15 \%$, maka nilai tambah tergolong rendah, 
2). Rasio nilai tambah $15-40 \%$, maka nilai tambah tergolong sedang, 3). Rasio nilai tambah $>40 \%$, maka nilai tambah tergolong tinggi. Nilai tambah tersebut masih termasuk nilai tambah kotor karena masih mengandung pendapatan tenaga kerja sebesar Rp. 3.076,- yang didapat dari koefisien tenaga kerja dikali dengan upah tenaga kerja. Didapat juga persentase bagian tenaga kerja sebesar $8,25 \%$. Hal ini sesuai dengan pendapat Aulia (2012) yang menyatakan bahwa nilai tambah ini diperoleh dari pengurangan nilai produk dengan harga bahan baku dan nilai input lain. Nilai tambah yang diperoleh masih merupakan nilai tambah kotor, karena belum dikurangi dengan imbalan tenaga kerja. Besar keuntungan yang diperoleh dari pengolahan kacang kedelai menjadi tempe sebesar Rp 34.233 per kg dengan tingkat persentase sebesar $68,4 \%$. Hal ini didukung oleh pendapat (Andani et al., 2015) yang menyatakan bahwa keuntungan tersebut merupakan selisih antara nilai tambah dengan imbalan tenaga kerja. Dengan demikian dapat dikatakan bahwa keuntungan tersebut termasuk keuntungan bersih yang diterima oleh pengrajin tempe.

\section{Uji Normalitas Nilai Tambah}

Hasil uji normalitas nilai tambah tahu dantempe dapat dilihat pada Tabel 7 berikut :

\begin{tabular}{llcc}
\multicolumn{4}{c}{ Tabel 7. } \\
\multicolumn{4}{c}{ Uji Normalitas } \\
\hline \hline No. & Keterangan & $\begin{array}{c}\text { Signi } \\
\text { fikansi }\end{array}$ & Kesimpulan \\
\hline 1. & $\begin{array}{l}\text { Nilai } \\
\text { Tambah }\end{array}$ & 0,012 & $\begin{array}{c}\text { Data Tidak } \\
\text { Normal }\end{array}$ \\
\hline
\end{tabular}

Sumber : Data Primer 2018

Berdasarkan Tabel 7 diatas dapat dilihat bahwa data nilai tambah tahu dan tempe berdistribusi tidak normal dengan hasil nilai signifikansi 0,012. Data dengan hasil signifikansi $>0,05$ berdistribusi normal sedangkan data dengan hasil signifikansi $<0,05$ berdistribusi tidak normal.

\section{Komparasi Nilai Tambah Tahu dan Tempe}

Hasil analisis komparasi nilai tambah tahu dan tempe dapat dilihat pada Tabel 8 berikut :

\section{Tabel 8.}

Komparasi Nilai Tambah

\begin{tabular}{lrcc}
\hline \hline No. & Keterangan & $\begin{array}{c}\text { Signi } \\
\text { fikansi }\end{array}$ & Kesimpulan \\
\hline 1. & Nilai Tambah & 0,000 & $\begin{array}{c}\text { Terdapat } \\
\text { Perbedaan }\end{array}$ \\
\hline
\end{tabular}

Sumber : Data Primer 2018

Berdasarkan Tabel 8 diatas dapat diketahui bahwa hasil komparasi nilai tambah tahu dan nilai tambah tempe mempunyai nilai signifikansi 0,000 yang artinya data tersebut terdapat perbedaan karena < 0,05. Analisis uji beda menggunakan analisis mann whiteney dikarenakan data hasil uji normalitas menunjukkan hasil tidak normal. Hal ini sesuai dengan penelitian (Tunggadewi, 2009) yang menyatakan bahwa terdapat perbedaan antara nilai tambah tahu dan nilai tambah tempe dengan hasil nilai tambah tahu lebih besar dibandingkan hasil nilai tambah tempe.

\section{SIMPULAN}

Berdasarkan hasil penelitian dapat disimpulkan bahwa nilai tambah tahu lebih besar $64.800 \mathrm{Rp} / \mathrm{kg}$ kedelai dibandingkan nilai tambah tempe 37.300 $\mathrm{Rp} / \mathrm{kg}$ kedelai. Nilai tambah home industry tahu signifikan lebih tingggi dibandingkan tempe. 
DAFTAR PUSTAKA

Andani, A., Nyanyu, N. A., dan Rendi, D.D. 2015. Nilai tambah dan keuntungan agroindustri berbasis kedelai di Provinsi Bengkulu. Prosiding Semnas FKPTPI. 51-56.

Anggraini, P. D. 2017. Analisis efisiensi penggunaan faktor-faktor produksi dan pendapatan pada industri rumah tangga tempe kedelai di Kabupaten Klaten. (Tesis). Semarang. Universitas Diponegoro.

Aulia, G. R. 2012. Analisis nilai tambah dan strategi pemasaran usaha industri tahu di Kota Medan. (Skripsi).Medan. Universitas Sumatera Utara.

Azmita, N., Vonny, I., M., dan Rian, H. 2019. Analisis nilai tambah dan profitabilitas usaha tahu alami di Kecamatan Koto Tengah Kota Padang. Journal of socio economic on Tropical Agriculture. 1 (3) : 3039.

Badan Pusat Statistik. 2016. Produksi 1993-2015. Badan Pusat Statistik, Jakarta Pusat.

Badan Pusat Statistik. 2017.diakses dari http://www.bps.go.id/, diakses pada tanggal 19 Juni 2017 pada jam 9:16 WIB.

Badan Pusat Statistik Grobogan. 2019. Kabupaten Grobogan Dalam Angka 2019. Badan Pusat Statistik Grobogan, Grobogan.

Budiman, A., J. Yusri dan E. Tety. 2014. Analisis efisiensi dan nilai tambah agroindustry tahu di Kota Pekanbaru. Jurnal Online Mahasiswa (JOM) Bidang Pertanian, 1(1) : 1-12.

Chrismahendra, E.,S. 2017. Analisis pemilihan bahan baku produksi tahu (kajian nilai tambah produksi kedelai lokal dan kedelai impor) di perusahaan tahu Bapak Dian
Hermawan. (Thesis). Malang. universitas Muhammadiyah Malang.

Haliza, W., E. Y. Purwani dan R. Thahir. 2016. Pemanfaatan kacang-kacangan local sebagai substitusi bahan baku tempe dan tahu. Buletin Teknologi Pasca Panen, 3(1) : 1-8.

Harinaldi. 2005. Prinsip-prinsip Statistik untuk Teknik dan Sains. Erlangga, Jakarta.

Hayami, Y., T. Kawagoe., Y. Morooka dan M. Siregar. 1987. Agricultural Marketing and Processing in Upland Java A Perspective from A Sunda Village. CGPRT Centre, Bogor.

Pratama, R. A. 2015. Analisis nilai tambah kedelai pada produk industry rumah tangga pengolahan tahu di Kecamatan Natar Kabupaten Lampung Selatan. (Skripsi).Lampung. Sekolah Tinggi Ilmu Pertanian Dharma Wacana.

Santoso, S. 2010. Statistik Parametrik. PT Elex Media Komputindo, Jakarta.

Saragih, Y. P. 2001. Membuat Aneka Tahu. Niaga Swadaya, Jakarta.

Siagian, D., dan Sugiarto. 2006. Metode Statistika untuk Bisnis dan Ekonomi. Gramedia Pustaka Utama, Jakarta.

Soehyono, F., Rochdiani, D., dan Yusuq, M. N. 2017. Analisis usaha dan nilai tambah agroindustri tempe. Jurnal Ilmiah Mahasiswa Agroinfo Galuh. 1 (1). 43-50.

Sutrisno, E. 2006. Studi Profil Industri Tempe Berdasarkan Tingkat Kesuksesan (Studi kasus industri tempe di Kecamatan Parung, Bogor). (Skripsi). Bogor. Institut Pertanian Bogor.

Tunggadewi, A. T. 2009. Analisis Profitabilitas Sera Nilai Tambah Usaha Tahu dan Tempe (Studi kasus di Kecamatan Tegal Gundil dan Cilendek Timur Kota Bogor). 
(Skripsi). Bogor. Institut Pertanian Bogor.

Wardani, C. R. 2008. Analisis Usaha Pembuatan Tempe Kedelai di Kabupaten Purworejo. (Skripsi). Surakarta. Universitas Sebelas Maret.
Wiyono, T., dan Rukavina, B. 2015. Analisis pendapatn dan nilai tambah usaha tahu pada industri rumah tangga "Wijianto" di Desa Ogurandu Kecamatan Bolano Lambunu Kabupaten Parigi Moutong. Jurnal Agrotekbis. 3 (3) : 421-42 